\title{
Anterior thoracic intradural arachnoid cysts
}

\section{Case report and review of the literature}

\section{Gerardo Caruso, M.D., Antonino Germanò, M.D., Mariella Caffo, M.D., Massimo Belvedere, M.D., Giovanni La Rosa, M.D., Oreste De Divitiis, M.D., and Francesco Tomasello, M.D. \\ Neurosurgical Clinic, University of Messina School of Medicine, Messina, Italy.}

Anterior thoracic intradural arachnoid cysts (ATIACs) are a rare cause of spinal cord and nerve root compression, for which different treatment strategies have been proposed. Although ATIAC represents a well-known clinical entity, the choice of surgical method has not been uniform, and no study has been specifically designed to compare the results of the different treatment options adopted.

The authors report the case of a 40-year old man with a 1-year history of dorsal pain, weakness in the lower extremities, gait disturbance, and mild sexual and urinary dysfunction. On neurological examination spastic paraparesis, lower-extremity hypertonia, and hypesthesia below T-2 were demonstrated. Magnetic resonance imaging revealed the presence of an ATIAC at the T-2 level. The patient underwent complete microsurgical removal of the cyst.

The authors conducted a Medline search of the relevant literature from 1966 to 1998 and also obtained data on other cases in which patients underwent surgical treatment of ATIAC. The literature search yielded five such cases. Treatment strategies were complete excision and fenestration followed by placement of a shunt. In addition, one case was characterized by intraoperative cyst rupture during retraction of the spinal cord.

Correct preoperative workup coupled with microneurosurgical technique allow for successful removal of the lesion and excellent outcome. Based on the literature review and the results in our case, the complete excision of ATIAC is associated with an excellent outcome, which is different from results achieved using other surgical strategies.

Key Words * arachnoid cyst * intradural * microneurosurgery * thoracic spine

Anterior thoracic intradural arachnoid cysts (ATIACs) are a well-known entity despite the paucity of published literature on the subject. First described in 1959 by Kuhlendahl, et al.,[15] they have been considered a developmental collection of cerebrospinal fluid (CSF) that is contained within the arachnoidal membrane and subarachnoid space, causing a rare form of spinal cord and nerve root 
Different surgical options for treatment of ATIAC have been proposed. In the past these cysts were not considered amenable to complete resection without causing undue manipulation of the cord.[20] Fenestration[21] combined with placement of a shunt in the subarachnoid space[20] and complete excision[26] have been consequently performed with different results.

In this report we describe an additional case of ATIAC. The indications for surgery, the treatment strategies adopted by different authors, the advantages and disadvantages of each surgical options, and long-term outcomes are reported in the light of the more recently published literature.

\section{CASE REPORT}

Presentation and Examination. This 40-year-old man who was referred to our institution presented with a 1-year history of progressive dorsal pain. The week before admission, the patient experienced mild weakness in the lower extremities with gait disturbance, and he complained of mild sexual and urinary dysfunction. No history of trauma was recorded. A neurological examination revealed moderate spastic paraparesis associated with lower-extremity hypertonia. Sensory changes consisted of hypesthesia below the T-2 level. Urinary and anal sphincters were partially uncontrolled. Magnetic resonance (MR) imaging was performed using a 1.5 tesla superconducting system in which the turbo spin-echo technique was utilized.

Magnetic resonance (MR) imaging of the spine revealed an intradural lesion at T2-3 that measured $2.5 \mathrm{X}$ $3.5 \mathrm{~cm}$. The mass appeared slightly hypointense on $\mathrm{T}_{1}$-weighted MR images (Fig. 1 upper). The cyst was not discernible on $\mathrm{T}_{2}$-weighted $\mathrm{MR}$ images, displaying signal characteristics similar to CSF. No enhancement was observed after gadolinium administration. 


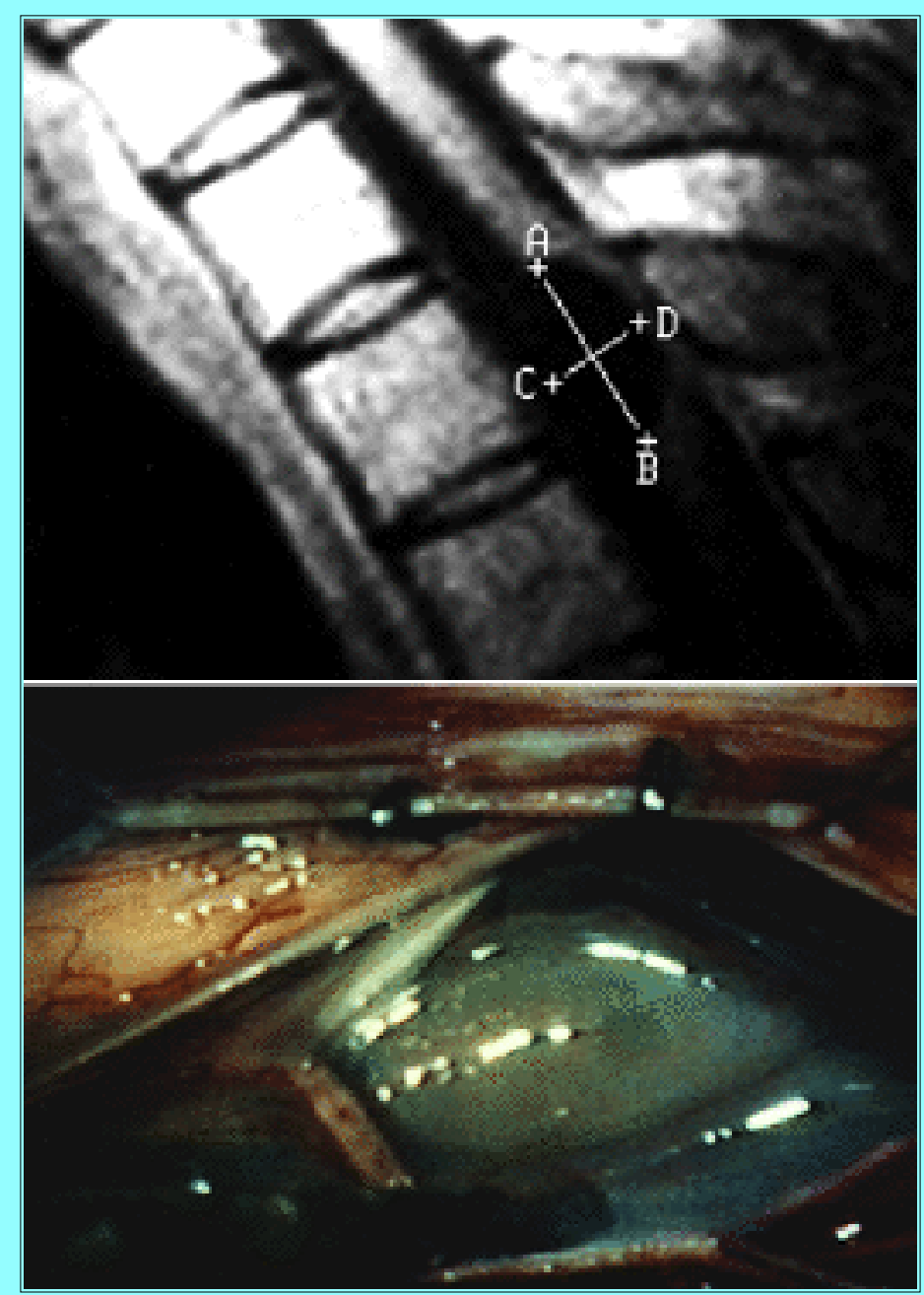

Fig. 1. Upper: Sagittal midline $\mathrm{T}_{1}$-weighted $\mathrm{MR}$ image revealing a hypointense mass anterior to the spinal cord at the T2-3 level, measuring $2.5 \times 3.5 \mathrm{~cm}$ and displacing posteriorly and flattening the cord. Lower: Intraoperative photograph. When the dura was opened, the spinal cord appeared posteriorly displaced and markedly flattened by an anterior arachnoid cyst.

Operation. The patient underwent a T1-3 laminectomy. When the dura was opened, the spinal cord appeared to be displaced posteriorly and was flattened by an anterior cyst (Fig. 1 lower). The cyst was opened and found to contain CSF. After the content was aspirated, the cyst was completely dissected from the surrounding structures by using standard microneurosurgical technique. Blunt dissection allowed cyst removal and reconstruction of the spinal subarachnoid space with respect to the spinal cord, nerve roots, and vascular network. On pathological evaluation of the cyst wall, areas of fibrocollagenous tissue with a single-cell cuboidal epithelial lining were found. The content of the cyst was sent for biochemical analysis, and the protein content was found to be $85 \mathrm{mg} / \mathrm{dl}$.

Postoperative Course. Postoperatively the patient's neurological status progressively improved. Complete removal of the cyst was confirmed on inspection of early postoperative MR study. At 1-year follow-up examination intermittent claudication and sphincter muscle disturbances had disappeared, and the patient had gradually regained sexual function. At 2-year follow-up examination the patient displayed no residual neurological deficit and had returned to his previous work and lifestyle. Evaluation of an MR study obtained at this time confirmed no recurrence of the ATIAC or spinal arachnoiditis, and the subarachnoid spaces were restored. However, the spinal cord was slightly displaced posteriorly from 
T2-3, presumably secondary to a congenital pathology that produced longlasting spinal cord dislocation and compression (Fig. 2).

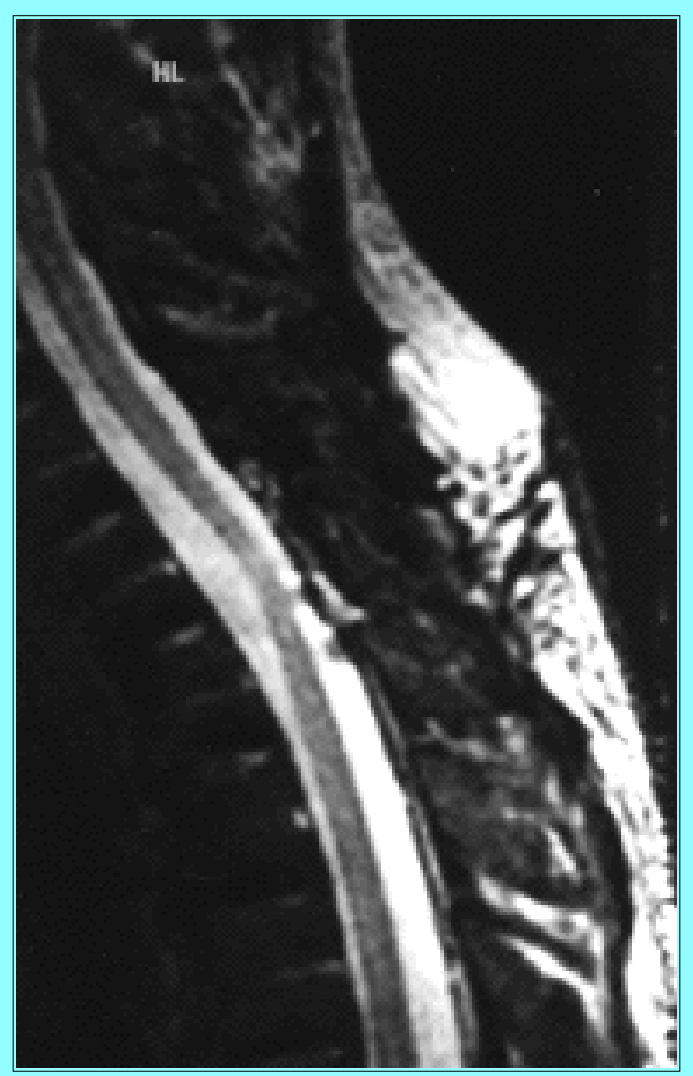

Fig. 2. Postoperative axial $T_{2}$-weighted $M R$ image demonstrating complete cyst removal and restoration of free subarachnoid spaces; there is no sign of cyst recurrence or spinal arachnoiditis. A slight posterior displacement of the spinal cord was still present.

\section{LITERATURE REVIEW}

We conducted a search of the relevant English literature in the Medline database published between 1966 and 1998 and also utilized other case reports described during previous years[15,26] in which patients were treated for ATIAC. In the search we used the following key words: arachnoid cyst, intradural, spinal, and thoracic. Only patients who harbored symptomatic and radiologically documented ATIACs were included in this study. We excluded those cases in which ATIAC presented in association with additional disease such as spinal hemangioma,[3] spinal lipoma,[20] tethered cord,[20] myelomeningocele,[24] syringomyelia,[3,24] or lesions located at cervicodorsal and dorsolumbar junction or in patients with previous history of spinal operations, $[3,10,20,24]$ and spinal arachnoiditis following use of fibrin glue.[29] Demographic and clinical data were collected from each series. The treatment options and long-term postoperative results, together with follow-up length, were recorded.

The literature search yielded four case series in which there were five eligible patients who underwent surgery for ATIAC.[15,20,21,26] Table 1 provides a summary of demographic data, cyst location, preoperative clinical findings and duration of symptoms, treatment strategies, complications, follow-up length, and long-term outcome, as described in each series in our case. 

IN SIX CASES OF ATSIACS.

\begin{tabular}{|c|c|c|c|c|c|}
\hline Authors \& Year & $\begin{array}{c}\text { Age, [yrs] } \\
\text { Sex }\end{array}$ & $\begin{array}{l}\text { Location } \\
\text { of Cyst }\end{array}$ & $\begin{array}{l}\text { Duration of Symptoms } \\
\text { \& Preop Findings }\end{array}$ & Operation & $\begin{array}{l}\text { Follow-up Length \& } \\
\text { Long-Term Outcome }\end{array}$ \\
\hline $\begin{array}{l}\text { Kuhlendahl, } \\
1959\end{array}$ & $9, F$ & $\mathrm{~T} 2-3$ & $\begin{array}{l}9 \text { mos; spastic parapa- } \\
\text { resis, hypesthesia be- } \\
\text { low }-4 \text {, Babinski's sign, } \\
\text { urinary disturbances }\end{array}$ & $\begin{array}{l}\text { complete } \\
\text { excision }\end{array}$ & $\begin{array}{l}\text { exoellent ; no neurological def- } \\
\text { icits; able to return to pre- } \\
\text { vious le vel of work \& lifestyle }\end{array}$ \\
\hline $\begin{array}{l}\text { Schisano, et al., } \\
1961\end{array}$ & $48, M$ & $T 5-7$ & $\begin{array}{l}30 \text { mos; thoradic pain, } \\
\text { paraparesis, Babinski's } \\
\text { sign, hypesthesia below } \\
\text { T-8 }\end{array}$ & $\begin{array}{l}\text { complete } \\
\text { excision }\end{array}$ & $\begin{array}{l}6 \text { yrs; excellent; no neurologi- } \\
\text { cal deficits; able to re tum to } \\
\text { previous le vel of work } \& \\
\text { lifestyle }\end{array}$ \\
\hline Palmer, 1974 & $25, \mathrm{~F}$ & T-8 & $\begin{array}{l}10 \text { days; spastic para- } \\
\text { paresis, hypesthesia } \\
\text { below T-8 }\end{array}$ & $\begin{array}{l}\text { in traop rup- } \\
\text { ture during } \\
\text { spinal cord } \\
\text { retraction }\end{array}$ & $\begin{array}{l}5 \text { yrs; good; mild deficits (t } \\
\text { leg meak \& stiff) but able to } \\
\text { return to premorbid work \& } \\
\text { lifestyle } \\
7 \text { yrs; parapare sis, increased } \\
\text { reflexes, hypesthesia below } \\
\text { T-8; reop for adhesions in } \\
\text { absence of recurrence } \\
10 \text { yrs; good; mild deficits } \\
\text { (hype sthesia belo wT-10) but } \\
\text { able to retum to premortid } \\
\text { work \& lifestyle }\end{array}$ \\
\hline $\begin{array}{l}\text { Osentach, } \\
\text { et al., } 1992\end{array}$ & $77, \mathrm{~F}$ & $T 6-10$ & $\begin{array}{l}\text { paraparesis, hypesthe- } \\
\text { sia. }\end{array}$ & $\begin{array}{l}\text { fenestration } \\
\text { \& shunting }\end{array}$ & $\begin{array}{l}\text { poor; significant deficits (senso- } \\
\text { ry im prowement, no motor } \\
\text { change, wheelchair bound) } \\
\text { requiring full-time nursing } \\
\text { care }\end{array}$ \\
\hline & $63, F$ & $T-9$ & $\begin{array}{l}\text { unspedied motor } \\
\text { deficits }\end{array}$ & $\begin{array}{l}\text { fenestration } \\
\& \text { shunting }\end{array}$ & $\begin{array}{l}6 \text { mos; poor; significant deficits } \\
\text { (urinary incontinence, worsen- } \\
\text { ing of motor functions) requir- } \\
\text { ing full-time nursing care }\end{array}$ \\
\hline present case & $40, M$ & $\mathrm{~T} 2-3$ & $\begin{array}{l}12 \text { mos; dorsal pain, } \\
\text { spastic paraparesis, } \\
\text { limb hypertonia, hyp- } \\
\text { esthesia below T-2, } \\
\text { mild sphincter \& } \\
\text { semual disturbances }\end{array}$ & $\begin{array}{l}\text { complete } \\
\text { excision }\end{array}$ & $\begin{array}{l}2 \text { yrs; excellent; no neurologi- } \\
\text { cal deficits; able to re tum to } \\
\text { previous le vel of work } 8 \\
\text { lifestyle }\end{array}$ \\
\hline
\end{tabular}

Intradural arachnoid cysts of the thoracic spine exhibit a female gender predominance (female/male ratio 2:1); age at the time of diagnosis ranged from 9 and 77 years (mean 43.6 years). Cysts were diffusely distributed throughout the thoracic spine. The time of symptom onset to diagnosis varied widely, ranging from 10 days to 30 months (mean 12.8 months), although in two cases it was not specified. All patients suffered motor deficits; the most frequent additional presenting symptoms and neurological signs were pain and hypesthesia. In addition, in one third of cases the occurrence of sphincter/sexual disturbances and positive Babinski's sign were described. The treatment strategies adopted in these cases were complete excision (three cases) and fenestration followed by shunt placement (two cases). In one case the cyst was ruptured, during the course of spinal cord retraction.[21] Seven years later, this patient underwent reoperation for arachnoidal adhesions because of progressive paraparesis, increased reflexes, and hypesthesia below T-8.

It is difficult to compare the long-term outcome data among these series because no accurate descriptions of the postoperative neurological results and of follow-up times exist. There were no deaths. The 
duration of follow-up periods ranged from 6 months to 10 years, although it was not specified in one case. The long-term outcomes were excellent (no neurological deficits, with patients able to return to previous work and lifestyle) in two cases, good (mild deficits but able to return to premorbid lifestyle) in one case, and poor (significant deficits requiring full-time nursing care) in two cases. In the two patients who underwent complete cyst excision excellent outcome was achieved. The two patients who underwent fenestration followed by shunt placement had a poor result. In the patient in whom the cyst ruptured during surgery, a good outcome was achieved.

\section{DISCUSSION}

Spinal intradural arachnoid cysts are among the rarest causes of symptomatic spinal cord and nerve roots compression. $[9,16,20]$ In the past such terms as arachnoid diverticula, subdural arachnoid cysts, meningeal hydrops, leptomeningeal cysts,[31] and arachnitis cystica[15] have been applied to these lesions. The pathogenesis of arachnoid cysts is still controversial. Some authors have contended that arachnoid cysts arise from arachnoidal trabecular cell proliferation in the septum posticum of Schwalbe.[23] However this hypothesis does not explain the occurrence of cysts found in the lumbar or anterior spine. It was believed that areas of reduced resistance at the level of arachnoidal granulation were related to variations in CSF hydrodynamics that allowed for cyst formation. [8] In this view the mechanism of cyst enlargement may be related to a one-way valve effect.[18,28] This theory of malformation is supported by the frequent association with other developmental abnormalities found in the central nervous system.[7,8,17,18,20,24,25,27] The familial occurrence of cysts has also been reported.[1] Other descriptions include the association of ATIAC with neural tube defect,[24] hereditary diastichiasis,[25,27] neurocutaneous melanosis,[11] myelomeningocele,[7,24] and diastematomyelia.[5,22] Furthermore, ATIAC may also be acquired. Inflammation,[1,2,7,12,16,21] trauma,[2,8,17,26] hemorrhage, [4] previous surgery, [2,30] lumbar puncture, [14,32] and the use of fibrin glue[29] have been implicated as causal factors. These cysts may become symptomatic secondary to mechanical (compression and traction on the spinal cord and nerve roots) $[8,9,12,26]$ and vascular factors (interference with the blood supply).[9,21] The intermittent emptying and filling of the cyst with change in body position,[20] angiographic evidence of medullary artery compression in which disturbances of venous return occur,[16] and chronic spinal cord and nerve roots ischemia[16] have been attributed to cyst symptomatology. The diagnosis of this entity has certainly been simplified and rendered more specific by the availability of MR imaging because it depicts noninvasively the extent and the site of the lesion, as well as suggests the nature of the lesion.[10,24] On $\mathrm{T}_{1}$-weighted MR sequences anatomical delineation of the lesion is provided. The cyst demonstrates signal characteristics similar to CSF on all sequences, including $\mathrm{T}_{2}$-weighted, fast spin-echo, and proton-density images. The signal characteristics of the cyst's content, as evaluated by the modulus variant of inversions recovery and turbospin-echo sequences, allow it to be distinguished from cystic neoplasm,[10] hemorrhage,[13] colloid cyst,[10,13] psammoma bodies, [6] and other cystic processes. Characteristically, there is no enhancement after gadolinium administration. Magnetic resonance (MR) imaging may lack specificity the absence of spinal cord displacement and flattening and when the cyst's contents show identical $\mathrm{T}_{1}$ - and $\mathrm{T}_{2}$ signal intensity as CSF.[19]

Knowledge of long-term morbidity associated with ATIAC is essential for patients and their families. Therefore, precise information regarding the long-term prognosis, especially as it relates to return to health and work, is important both in planning for the future and in establishing and maintaining a realistic, but positive attitude toward surgery and rehabilitation. 
Indications for surgery include progressive complaints of pain and/or neurological deficits.[2,9] In the large series of Lesoin, et al.,[16] the authors reported that the prognosis of arachnoid cyst of the spine depends primarily on the duration of neurological symptoms; furthermore, if timely surgical treatment is not performed, neurological deficits may progress and become irreversible.[16] In the past ATIACs were not considered amenable to complete resection without causing undue manipulation of the cord.[20] Consequently, over the years many surgical options have been proposed for treatment of patients with ATIAC. The proper selection of surgical strategy requires accurate assessment of the risk-benefit ratio of different treatments in the light of the natural history of the disease and long-term results. In the cases in which fenestration of the cyst was performed, a major disadvantage was the late closure of the opening due to scarring phenomena. $[7,17,21]$ To prevent this, some authors have inserted a catheter in the fenestration, shunting the cyst into the subarachnoid space. Although shunting avoids late closure of the fenestration, it is accompanied by a higher incidence of additional shunt-related complications and life-long shunt dependence.[20,21] In most cases, improved intraoperative techniques in neurosurgery have permitted greater degrees of resection of spinal pathologies than were possible in earlier times. Careful microsurgical dissection of subarachnoid cyst adhesion, with careful attention not to disturb spinal cord structures, nerve roots, and vascular network, allows for safe cyst removal in the absence of any adjunctive neurological dysfunction and allows for achievement of an excellent outcome. In addition, based on the results of the Medline literature review and on our case, we think that complete ATIAC excision is the only procedure associated with an excellent outcome, whereas other surgical treatments achieved long-term outcomes ranging from poor to good. We recognize that the data presented here are not substantial enough to provide a definitive conclusion, primarily because of the large number of variables involved in the prognosis of ATIAC, the different outcomes reported in the literature, and the fact that our results are based on a limited number of patients. However, the feasibility of radical microsurgery supports a recommendation to perform a complete resection of ATIACs. The excellent postoperative clinical improvement achieved in our case and others[15,26] by using complete cyst excision highlights this strategy as the therapeutic choice for treating these lesions.

\section{References}

1. Aarabi B, Pasternak G, Hurko O, et al: Familial intradural arachnoid cysts. Report of two cases. J Neurosurg 50:826-829, 1979

2. Alvisi C, Cerisoli M, Giulono M, et al: Long-term results of surgically treated congenital intradural spinal arachnoid cysts. J Neurosurg 67:333-335, 1987

3. Andrews BT, Wenstein PR, Rosenblum ML, et al: Intradural arachnoid cysts of the spinal canal associated with intramedullary cysts. J Neurosurg 68:544-549, 1988

4. Burger PC, Vogel FS: Surgical Pathology of the Nervous System and its Coverings, ed 2. New York: John Wiley, 1982, pp 593-600

5. Cilluffo JM, Redmond MJ, Ebersold MJ: Idiopathic thoracic intradural and extradural arachnoid diverticula. Report of a case. Acta Neurochir 65:199-206, 1982

6. Dietemann JL, Filippi de la Palavesa MM, Kastler B, et al: Thoracic intradural arachnoid cyst: possible pitfalls with myelo-CT and MR. Neuroradiology 33:90-91, 1991

7. Duncan AW, Hoare RD: Spinal arachnoid cysts in children. Radiology 126:423-429, 1978 
8. Fortuna A, Mercuri S: Intradural spinal cysts. Acta Neurochir 68:289-314, 1983

9. Galzio RJ, Zenobii M, Lucantoni D, et al: Spinal intradural arachnoid cyst. Surg Neurol 17:388-391, 1982

10. Jena A, Gupta RK, Sharma A, et al: Magnetic resonance diagnosis of spinal arachnoid cyst. A report of two cases. Childs Nerv Syst 6:107-109, 1990

11. Kasantikul V, Shuangshoti S, Pattanaruenglai A, et al: Intraspinal melanotic arachnoid cyst and lipoma in neurocutaneous melanosis. Surg Neurol 31:138-141, 1989

12. Kendall BE, Valentine AR, Keis B: Spinal arachnoid cysts: clinical and radiological correlation with prognosis. Neuroradiology 22:225-234, 1982

13. Kjos BO, Brant Zawadski M, Kucharazyk W, et al: Cystic intracranial lesions: magnetic resonance imaging. Radiology 155:363-369, 1985

14. Kriss TC, Kriss VM: Symptomatic spinal intradural arachnoid cyst development after lumbar mielography. Case report and review of the literature. Spine 22:568-572, 1997

15. Kuhlendahl H: [Spinal arachnoid cysts.] Zentralbl Neurochir 19:198-204, 1959 (Ger)

16. Lesoin F, Leys D, Rousseaux M, et al: Spinal intradural arachnoid cysts. Acta Neurochir 76:125-128, 1985

17. Lombardi G, Morello G: Congenital cysts of the spinal membranes and roots. Br J Radiol 36:197-205,1963

18. Nabors MW, Pait TG, Byrd EB, et al: Updated assessment and current classification of spinal meningeal cysts. J Neurosurg 68:366-377, 1988

19. Osborn AG: Diagnostic Neuroradiology. St. Louis: Mosby, 1994, pp 876-918

20. Osenbach RK, Godersky JC, Traynelis VC, et al: Intradural extramedullary cysts of the spinal canal: clinical presentation, radiographic diagnosis, and surgical management. Neurosurgery 30:35-42, 1992

21. Palmer JJ: Spinal arachnoid cysts. Report of six cases. J Neurosurg 41:728-735, 1974

22. Perret G: Symptoms and diagnosis of diastematomyelia. Neurology 10:51-60, 1960

23. Perret G, Green D, Keller J: Diagnosis and treatment of intradural arachnoid cysts of the thoracic spine. Radiology 79:425-429, 1962

24. Rabb CH, McComb JG, Raffel C, et al: Spinal arachnoid cysts in the pediatric age group: an association with neural tube defects. J Neurosurg 77:369-372, 1992

25. Robinow M, Johnson GF, Verhagen AD: Distichiasis-lymphedema. A hereditary syndrome of multiple congenital defects. Am J Dis Child 119:343-347, 1970

26. Schisano G: Cisti aracnoidee spinali. Acta Neurol 16:773-781, 1961

27. Schwartz JF, O'Brien MS, Hofffman JC Jr: Hereditary spinal arachnoid cysts, diastichiasis, and 
lymphedema. Ann Neurol 7:340-343, 1980

28. Spiegelmann R, Rappaport ZH, Sahar A: Spinal arachnoid cyst with unusual presentation. Case report. J Neurosurg 60:613.616, 1984

29. Taguchi Y, Suzuki R, Okada M, et al: Spinal arachnoid cyst developing after surgical treatment of a ruptured vertebral artery aneurysm: a possible implication of topical use of fibrin glue. Case report. J Neurosurg 84:526-529, 1996

30. Valls PL, Naul LG, Kanter SL: Paraplegia after a routine lumbar laminectomy: report of a rare complication and successful management. Neurosurgery 27:638-640, 1990

31. Wilkins RH, Odom GL: Spinal intradural cysts, in Vinken PJ, Bruyn GW, Braakman R, et al (eds): Injuries of the Spine and Spinal Cord. Handbook of Clinical Neurology, Vol 25/26. New York: Elsevier, 1976, pp 55-102

32. Zuccarello M, Powers G, Tobler WD, et al: Chronic posttraumatic lumbar arachnoid cyst with cauda equina compression: case report. Neurosurgery 20:636-638, 1987

Manuscript received March 16, 1999.

Accepted in final form March 26, 1999.

Address reprint requests to: Gerardo Caruso, M.D., Neurosurgical Clinic, Policlinico, University of Messina, 98122 Messina, Italy. email: citsal@eniware.it. 